\title{
Rolling a Role: Enhancing Critical Thinking and Communication Skills
}

\author{
Natasha Goel, Sangeeta Chauhan \\ GGSIPU \\ Delhi, India
}

\begin{abstract}
The promotion of critical thinking and communication skills has become more crucial in the present. Enhancing the capabilities of elementary school children, enables them to solve the kinds of complex problems encountered in real life situations. Rolling a role play as an innovative teaching technique can be considered as useful for enhancing critical thinking and communication skills. It provides a platform where students work together in potentially real life situations. The use of role play in teachinglearning situations emphasizes on cognitive, affective and psychomotor aspects of children. The aim of the present paper is to probe the usefulness of role play in promoting critical thinking and communication skills amongst elementary school children. Descriptive research design has been taken up wherein the investigators have attempted to study the identification of role play activities and its significance in enhancing critical thinking and communication skills amongst elementary school children. The present paper also probes the level of critical thinking amongst elementary school children.
\end{abstract}

\section{Introduction}

Tell me and I forget. Teach me and I remember. Involve me and I learn (Benjamin Franklin).

The education is at its best when it contributes all the beauty to the body, mind and soul. It aids in striking a balance between the mental, moral and physical aspects of human beings. Tagore remarked on the objective of education and refused to accept it as simply accumulating knowledge, rather it should be the holistic development in which physical, intellectual, aesthetic and spiritual growth should be synchronized with integral process. Thus the focus of education has been shifted to learner-centered curriculum. In contemporary times the aim of education is the holistic development of the learners. For this purpose educationists are designing activity centered curriculum which involves learners and demands from them the use of thinking skills, social skills, emotional skills and moral values to aid the effective learning. In order to make learning process more meaningful, the learners should not only be engaged cognitively but also physically and emotionally. Learners, when involved actively in the process of learning and relating what they are learning to the past experiences and applying it in the real life, lands into the long lasting memory. Learners should be trained to think logically, analyze, question and evaluate the content, this aids in the development and promotion of critical thinking and communications skills of the learners. Critical Thinking and communication skills can be developed effectively if learners are encouraged to deal efficiently with many of the practical situations. By transforming the curriculum to integrate active and evidence based practices will aid in development of critical thinking and communication skills. Role Play seemed to be an interesting and effective tool to accomplish those requirements. As an interesting tool, as it motivates students and create joyful learning and effective because it deals with a variety of aspects of language and communication. Role Plays have been used comprehensively among several disciplines and enriches learning in several areas. It not only facilitates learning but also plays an important role in modifying the conduct of the learners.

\section{Key Terms}

\subsection{Role Play}

Learners assume a role and play as if they are somebody else in a pre-defined situation. Play means that the role is taken on in a safe environment where students can be as inventive and playful as possible [5]. The technique of role play is representing a character and replicating the character's thoughts and emotions.

Table 1. Role Play Activities

\begin{tabular}{|l|l|l|}
\hline S.No. & \multicolumn{1}{|c|}{ Activity } & \multicolumn{1}{|c|}{ Description } \\
\hline 1. & Famous People & $\begin{array}{l}\text { A guessing game in } \\
\text { which students adopt the } \\
\text { roles of famous people. }\end{array}$ \\
\hline 2. & $\begin{array}{l}\text { Story telling } \\
\text { through Role } \\
\text { plays }\end{array}$ & $\begin{array}{l}\text { Students role plays the } \\
\text { characters of a story and } \\
\text { enact }\end{array}$ \\
\hline
\end{tabular}




\begin{tabular}{|l|l|l|}
\hline 3. & Roll a role & $\begin{array}{l}\text { Students use cubes as } \\
\text { dice to set up a random } \\
\text { role play situation. }\end{array}$ \\
\hline 4. & $\begin{array}{l}\text { Mock } \\
\text { Parliament }\end{array}$ & $\begin{array}{l}\text { Students play roles of } \\
\text { different politicians and } \\
\text { enact a scene of } \\
\text { parliament. }\end{array}$ \\
\hline 5. & Barter Express & $\begin{array}{l}\text { Students negotiating and } \\
\text { bartering things. }\end{array}$ \\
\hline
\end{tabular}

\subsection{Critical Thinking}

By the American Philosophical Association, a comprehensive investigation was organized as an effort to reach an accord of opinion by a panel of 42 experts in Critical Thinking from various disciplines for the purpose of educational instruction and assessment [3]. Facione and Facione [4] in the Delphi report defined Critical Thinking as purposeful, self-regulatory judgment which results in interpretation, analysis, evaluation and inference, as well as explanation of the evidential, conceptual, methodological, criteriological or contextual considerations upon which that judgment is based. Facione [3] has mentioned the dimensions of Critical Thinking which consist of:

2.2.1. Cognitive Skills: The cognitive critical thinking skills are defined as the mental abilities involved in critical thinking. Following are the sub skills:

- Interpretation: categorization, decoding significance, clarifying meaning

- Analysis: examining ideas, identifying arguments, analyzing arguments

- Evaluation: assessing claims, assessing arguments

- Inference: querying evidence, conjecturing alternatives, drawing conclusions

- Explanation: stating results, justifying procedures, presenting arguments

- Self-Regulation: self-examination, self correction

2.2.2. Affective Dispositions: The Affective Critical Thinking Dispositions are defined as habitual inclination or tendency to think critically. Following are the subskills:

a) Approaches to life and living in general:

- inquisitiveness with regard to a wide range of issues,

- concern to become and remain generally wellinformed,

- alertness to opportunities to use CT,

- trust in the processes of reasoned inquiry,
- self-confidence in one's own ability to reason,

- open-mindedness regarding divergent world views,

- flexibility in considering alternatives and opinions,

- understanding of the opinions of other people,

- fair-mindedness in appraising reasoning,

- honesty in facing one's own biases, prejudices, stereotypes, egocentric or socio-centric tendencies,

- prudence in suspending, making or altering judgments,

- willingness to reconsider and revise views where honest, reflection suggests that change is warranted.

b) Approaches to specific issues, questions or problems:

- clarity in stating the question or concern,

- orderliness in working with complexity,

- diligence in seeking relevant information,

- reasonableness in selecting and applying criteria,

- care in focusing attention on the concern at hand,

- persistence though difficulties are encountered,

- precision to the degree permitted by the subject and the circumstance.

\subsection{Communication Skills}

Communication preserves a peaceful co-existence and understanding amongst human beings. It can be described as a process of transmitting ideas, information, messages and receiving feedback. It frames an integral feature of human activities thereby making it more essential to be developed in learners. For the study the communication skills comprise Verbal (speaking skills), Non-Verbal (gestures and Writing skills).

\section{Review of Related Literature}

Rashid and Qaisar [7] investigate the usefulness of role play strategy in the development of critical thinking among elementary students and found that role playing is a productive teaching approach in promoting critical thinking in Pakistani context. Fabio [2] in his study analyzed the impact of drama activities both on the development of students' speaking skills and their motivation at secondary stage. He also emphasized on development of students' creativity, ideas and critical thinking. It was found that drama activities offered the perfect tools to accomplish that, involving both the learner's intellectual and emotional sphere. Albalawi [1] investigated the influence of teaching English 
subject using drama on the development of intermediate students' critical and creative thinking. Yusuf and Adeoye [8] constructed a five-step model and task-based activities for the development of critical thinking and communicative competence amongst students.

\section{Research Questions}

4.1. What are the role play activities conducted in different disciplines at elementary school level?

4.2. What is the level of critical thinking amongst elementary school children?

4.3. What is the significance of role play in enhancing critical thinking amongst elementary school children?

4.4. What is the significance of role play in enhancing communication skills amongst elementary school children?

\section{Objectives of the Study}

The following are the objectives of the present study:

5.1. To identify the role play activities conducted in different disciplines at elementary school level.

5.2. To study the level of critical thinking amongst elementary school children.

5.3. To study the use of role plays in enhancing critical thinking amongst elementary school children.

5.4. To study the use of role plays in enhancing communication skills amongst elementary school children.

\section{Methodology}

\subsection{Research Design}

Descriptive research design has been taken up wherein the investigators have attempted to identify the role play activities undertaken at elementary school level. The use of role play in enhancing critical thinking and communication skills amongst elementary school children has also been explored.

\subsection{Sample}

50 Students of class VIII of a senior secondary school of Delhi comprise as the sample. Random sampling has been taken up for the selection of school and the sample.

\subsection{Tools}

Following tools were used for the data collection: 6.3.1. Checklist (prepared by the investigators) has been used for identifying the role play activities conducted in different disciplines at elementary level.

6.3.2. Murthy Critical Thinking Scale [6] has been used to assess the level of critical thinking amongst elementary school children.

6.3.3. Questionnaire (prepared by the investigators) has been used to assess the critical thinking amongst elementary school children.

6.3.4. Rubrics (prepared by the investigators) have been used to assess the communication skills amongst elementary school children.

\subsection{Delimitation}

The following delimitation, with respect to the present study, were taken into account

a) The study was conducted at the elementary school level.

b) It was conducted at Class VIII level

\section{Results and Discussion}

\subsection{Objective one}

To identify the role play activities conducted in different disciplines at elementary school level.

In order to identify the role play activities conducted in different disciplines in school, the investigators prepared a checklist. Following observations were made:

a) Most of the role plays performed was group activities.

b) Science and language subjects conducted more role plays than any other subjects.

c) The activities performed promoted verbal linguistic, problem solving, bodily kinesthetic and interpersonal intelligence.

d) Story telling through role play was the most common activity conducted in almost every subject.

\subsection{Objective two}

To study the level of critical thinking amongst elementary school children. In order to assess the level of critical thinking amongst elementary school children, the investigators adopted a standardized tool prepared by C.G.V. Murthy [6], Murthy Critical Thinking Scale. The scale contains four conflicting situations and children have to write merits and demerits. They are 
also expected to write how to conclude opinion for every situation. Following results were observed:

a) Process of thinking: $52 \%$ of the children fall into the category of good process of thinking, that is they are quick thinker, matured thinker and very good critical thinker. $28 \%$ of the children fall into the category of average process of thinking, that is they are impulsive and risk-taking type thinker, dwarf thinker, good analyzer and mediocre synthesizer. $20 \%$ of the children fall into the category of poor process of thinking, that is they are poor critical thinker, good analyzer and poor synthesizer.

b) Product of thinking:

26 children have good ability to conclude. 14 children have average ability to conclude. 10 children have poor ability to conclude.

\subsection{Objective three}

To study the use of role plays in enhancing critical thinking amongst elementary school children.

For the purpose of assessing the critical thinking amongst elementary school children the investigators prepared questionnaire. A mixed type questionnaire was prepared. Following results were observed:

a. Most of the children opined that using role play has increased their self-confidence.

b. A little more than half of the children opined that role play has helped them in presenting the information in logical sequence with a clear connection between ideas, arguments and statements.

c. One-third of the children are willing to reconsider and revise the changes that are suggested to them.

d. Half of the children believed that role play has helped them in clearly stating the issues and concerns.

\subsection{Objective four}

To study the use of role plays in enhancing communication skills amongst elementary school children. For assessing the communication skills amongst elementary school children, the investigators prepared rubrics. The communication skills of the children were assessed during and after the role play performance. Both verbal (Speaking skill) and nonverbal (Gestures and writing skills) communication skills were assessed. Following observations were made:

a) During Performance (Speaking skill and Gestures):
- The content delivered by most of the children was accurate, organized and relevant.

- Vocabulary used was simple and appropriate to audience and topic.

- Most of the children had clear pronunciation, varied stress and intonation in keeping with the task and content.

- Most of the children were fluent, having clear speech and easy to understand.

b) After Performance (Writing skill):

- Some children organized the content properly, using adequate structures

- Few children had grammatically accurate content and there were no inaccuracies in punctuation.

- Only a few children had no in accuracies in spelling.

\section{Implications}

\subsection{For Children}

- To enhance critical thinking amongst children, they may be motivated and made aware of their capabilities.

- They may be encouraged to build a habit of thinking beyond convention.

- Children should be encouraged to make efforts to overcome their weaknesses and work towards their strengths.

\subsection{For Teachers}

- Teachers should encourage the ideas, thoughts and feelings of children.

- Teachers should give opportunities to children to express and enhance their confidence level.

- They should use role plays frequently to maintain the interest of children in the subject.

- They should know when to intervene during the role play and give their feedback to children.

\subsection{For School Administrators}

- School administrators should motivate teachers to organize role play activities with respect to their subject.

- Enough resources must be provided to teachers to organize role play activities. 


\section{Conclusion}

For the holistic development of the children, teachers must facilitate children by using innovative techniques in their classrooms for encouraging and enhancing the critical thinking and communication skills. Role play provides a productive environment for the promotion of critical thinking and communication skills amongst elementary school children. Such techniques have the potential to involve and engage children during learning process for longer duration and maintain their interest.

\section{References}

[1] Albalawi, B. R. (2014). Effectiveness of Teaching English Subject using Drama on the Development of Students' Creative Thinking. IOSR Journal of Research \& Method in Education (IOSR-JRME) e-ISSN: 2320-7388, p-ISSN: 2320737X Volume 4, Issue 6 Ver. I. Nov - Dec. 2014, PP 54-63.

[2] Fabio, T. (2015). Drama Techniques to enhance speaking skills and motivation in the EFL secondary classroom. Dated August 2015 Retreived from http://eprints.ucm.es/32553/

[3] Facione, N.C., Facione, P.A., (1996). Externalizing the critical thinking in clinical judgment. Nursing Outlook. Volume 44. p.p. 129-36.

[4] Facione, P.A. (1990). The Delphi Report. Critical Thinking: A Statement of Expert Consensus for Purposes of Educational Assessment and Instruction. Executive summary. Millbrae, California: The California Academic Press.

[5] Ladousse, G. P. (1992). Role play. Hong Kong: Oxford University Press. Oxford. 2014.

[6] Murthy, C.G.V., (2015). Murthy Critical Thinking Scale. Psychotronics, Bangaluru.

[7] Rashid and Qaisar (2017). Role Play: A Productive Teaching Strategy to Promote Critical Thinking. Bulletin of Education and Research August 2017, Vol. 39, No. 2 pp. 197 213

[8] Yusuf, Florence Adeoti, Adeoye, E. A. (2012). Developing Critical Thinking and Communication Skills in Students: Implications for Practice in Education. African Research review. An International Multidisciplinary Journal, Ethiopia Vol. 6 (1), Serial No. 24, January, 2012 ISSN 19949057 (Print) ISSN 2070--0083 (Online). P.p. 311-324) 